\title{
Adding Interest to Educational Practices Propositions for a Post-Critical Pedagogy
}

\author{
Hans Schildermans (University of Vienna)
}

\begin{abstract}
:
The aim of this paper is to outline a way of theory development in educational thinking that stays true to the insights and commitments of post-critical pedagogy, while at the same time drawing out a slightly different pattern. The paper suggests five different propositions that reformulate the Manifesto for a Post-Critical Pedagogy in a speculative-pragmatic mode, informed by the philosophies of Alfred North Whitehead, William James, and Isabelle Stengers. Central to this way of doing theory is that it is situated by actual educational practices and that theory development itself is conceived as a way of taking care of our abstractions through the formation of concepts. What is at stake in this mode of doing theory is adding interest to educational practices, making them come to matter in a particular way. In doing so, post-critical pedagogy offers a way of analyzing educational practices of the present and the past, while opening up possibilities for designing educational practices for the future, without defining what the future might look like.
\end{abstract}

Keywords:

abstraction; dramatization; educational practice; importance; Isabelle Stengers; post-criticality

\section{Prolegomenon}

After the demise of critique as the basic attitude of educational thinking, the question remains what the new philosophical gesture of educational theory might be. In this text, I propose to understand this gesture at once as a speculative and a pragmatic one, assuming that these two styles of thinking converge in their attention for consequences, possibilities, and contingencies, rather than foundations, principles, and necessities that are so central to the critical paradigm (James, 1907/2000; Whitehead, 1938/1968; see Savransky, 2017).

This text is written in response to the Manifesto for $a$ Post-Critical Pedagogy, formulating five propositions that, while staying loyal to the insights and commitments of post-criticality (Hodgson et al., 2018), attempt to draw out a slightly different pattern. I want to start, however, by making a distinction, namely between post-criticality as a philosophical system of educational concepts (e.g., pedagogical hermeneutics, hope in the present) on the one hand, and post-criticality as a philosophical attitude towards educational practices on the other hand. Of interest to me here is the latter, and in that sense, I approach postcritical pedagogy as a 'methodology' (i.e. as concerned with the question of how to learn something new).

One of the main tenets of this text is that practices are to be approached as concretely and specifically as possible. Therefore, it would not make sense to refer to practices in an all too general sense. In other words, it is not about teaching as a practice, or studying as a practice, but about a specific practice of teaching or a specific practice of studying. In order to clarify my argument, I will refer primarily to my work on the educational practice of Campus in Camps, an experimental university in a Palestinian refugee camp (Schildermans, 2021). ${ }^{1}$

Proposition I: Propositions Need to be Fabricated!

The first proposition situates the ensuing series of propositions in a harmonious divergence from the Manifesto, whose first principle is that "there are principles to defend” (Hodgson et al., 2018, p. 15). The distinction between principles and propositions is not just a difference in preference or style. The distinction is crucial since it situates the post-critical project in a different line of thinking, which allows for an alternative series of propositions to be made in the wake of the first one.

Principles have a foundational character in the sense that they refer to first things, to origins and beginnings, to necessities and categories. Principles express the assumptions that underly a mode of thinking or acting and delimit a territory within the borders of which this mode of thinking or acting is justified. In their capacity as borders, principles can be respected or violated, transgressed or indeed defended but they always exist as the walls that encircle the sanctioned. Essentially, principles seem still to pertain to a vocabulary that is in itself critical, i.e. eager to demarcate the legitimate from the illegitimate.

Propositions, in contrast, are not primarily respected or violated, transgressed or defended. Whitehead (1929/1978) writes that propositions are entertained, and "a proposition is entertained when it is admitted into feeling” (p. 188). 
Propositions do not aim to set out a rule or a border, but operate as invitations, luring their receivers into other ways of thinking and perceiving. This shifts the vocabulary from a critical one to a speculative one, presenting a lure for feeling, making us sensitive to "the insistence of possibles" (Debaise \& Stengers, 2017, p. 13), possibles that can be entertained and that invite us to put our thoughts at play.

The efficacy of propositions lies in the way in which they intensify experience by drawing attention to something that went unnoticed, force thought not to exclude anything by claiming it to be irrelevant or irregular. "The efficacy of propositions, the way they matter, is thus a suggestive one: they elicit interest, divert attention and propose a way something is taken into account” (Sehgal, 2014, p. 196). Put differently, propositions make something come to matter, and make it come to matter in one way rather than another.

Proposition II: Post-Critical Educational Pedagogy is Situated by Educational Practices, and it is in Paying due Attention to These Practices That it Develops its Concepts

A practice is to be understood here in the most concrete and specific sense, not just as a general set of habits and dispositions. For instance, the way in which the third generation refugees of Campus in Camps gathered to study the camp they were living in, can be grasped as a practice. Although this practice entails the activities of drawing maps, interviewing other inhabitants, and taking and arranging photographs, it is to be considered as a practice in and of itself. The practice, hence, comprises next to its human participants, also the materials required for the practice to take place, its specific time and space, the aims and ideas that surround it, and what is being said and done in the course of the practice (Schildermans, 2021). Practices are always enacted by a particular collective, in a particular moment, in a particular place.

Philosophically speaking, a practice is a series of singular events - in Whiteheadian terms one could call these “actual occasions” (Whitehead, 1929/1978, p. 18). In that sense, a practice is a holding together of different entities according to a pattern that endures throughout time. The different entities that are held together in the course of the practice are not limited to humans. The collective of the practice includes other-than-human entities as well, such as machines, animals, tools, maps, and even ideas. Claiming that practices proceed according to a pattern does not mean that there is some regularity underlying the practice that could be explicated in terms of social rules (see Wittgenstein's language games), and that would guarantee the endurance of a practice - at least as long as there are practitioners who 'know how to go on'. Rather, the endurance of the practice is itself of the order of the event. It is an achievement in creating ongoingness, and failing to achieve ongoingness means the dissolution of the practice, at that place, at that time.

While being situated by educational practices, postcritical pedagogy lives up to its promises of affirmation and immanence as basic attitudes of theory development. The selection of a practice to be theorized is in the first instance already an affirmation, "a realization of worth ... . Its basic expression is - Have a care, here is something that matters!” (Whitehead, 1938/1968, p. 116). In affirming educational practices, the post-critical gesture is one of drawing attention to educational practices that are worthy of endurance, that deserve to be cared for. The experimental university of Campus in Camps, for instance, comes forth as a remarkable or interesting practice to rethink the relation between university and society from the perspective of study. It is in thinking with practices, and hence affirming them, that post-critical pedagogy proceeds.

Moreover, it is in its most concrete and specific form that a practice has to be approached. This means to try to grasp a practice from the inside-out, on its own terms, instead of from the outside-in, from a transcendent point of view that would explain the practice in terms of generalities of which the practice would be just a case or an example. In that sense, a practice has to be approached like one would approach an animal that shies away, with hesitation and care, and not with big and brutal concepts and theories, for which the practice would just be an illustration. It is in paying due attention that post-critical pedagogy approaches educational practices.

Proposition III: Paying due Attention to Educational Practices Means Taking Care of the Abstractions With Which These Practices are Experienced

Taking care of our abstractions involves primarily drawing attention to what otherwise would have remained unnoticed. It is a way of countering what Whitehead (1938/1968) has called "The Fallacy of the Perfect Dictionary” (p. 173). This fallacy corresponds to the belief that we already know and have coined all the fundamental ideas that can be applied to our experience, and that these ideas can be explicitly expressed in concepts. Taking care of our abstractions has to do with paying attention to the way in which our abstractions lure our experience, what they render visible and invisible, the ways of acting they induce, the destructions they legitimize, and the possibles they make us sensitive to (see Stengers, 2014).

At first sight, Campus in Camps could be approached as practice of political activism for instance. When analyzing their work by investigating the ways they gather, the materials being produced, and the exercises being conducted, it turns out that their practice could also be grasped via a different set of abstractions that draw our attention to other dimensions that risk to remain neglected when recognizing their work too quickly as political 
activism. Those other dimensions include for instance their way of studying the camp. Abstractions are therefore not opposed to the 'real world'. Rather, they are part and parcel of our experience, and it is the 'real world', a world that is always unfinished, "in the making” (James, 1907/2000, p. 113), that presents a test or a challenge to our ways of thinking, "a 'reality' for our ideas to be become true of" (James, 1988, p. 237).

In that sense, this third proposition aligns the practiceoriented approach to post-criticality with the radical empiricism of William James. James (1912/2018) writes that "to be radical, empiricism must not admit in its constructions any element that is not directly experienced, nor exclude from them any element that is directly experienced" (p. 24). This means that our experience of a practice, the way in which we grasp it and relate to it, is as much part of the practice as its other constituent parts, the other entities being prehended. Therefore, a vital concern for post-critical pedagogy is to take care of the way in which we relate to educational practices, to take care of the abstractions with which we experience these practices, including what these abstractions allows us to perceive, and what consequences these perceptions entail.

Theory development in the post-critical mode is hence pragmatic in nature because it takes seriously that the reality of a world in the making always overshoots our abstractions of it, while at the same time being aware of the ways in which these abstractions play their part in the never-ending construction of that world. Therefore, by taking care of our abstractions of a specific educational practice, post-criticality introduces a break into the becoming of the practice that is being studied, while at the same time granting the practice the possibility to come to matter to problems and questions outside its scope, make the practice interesting for those who are situated outside the practice, but for whom it might provide a lure for feeling and thinking differently.

Proposition IV: The Post-Critical Technique of Writing is Dramatization, and it is in Dramatizing Educational Events That it Adds Interest to Educational Practices

To dramatize educational events means to situate them within the practices that allowed for their coming into being, to tell a story about a practice. Post-critical theory development could, hence, be understood as the writing of "the tales that perhaps might be told about particular actualities” (Whitehead, 1929/1978, p. 256). One could for instance construct a story about Campus in Camps as a group of political activists, but one could also tell a tale about a collective of studiers that raised the question what the right of return could still mean for them - a question that incited them to study the camp and the life of its inhabitants.
It is vital that such a change of story does not announce a general relativism, in which all stories become 'just' a story about a practice. With every new story, another grasp imposes itself, which makes come to matter what we used to omit, and which offers the possibility to slow down before what usually goes without saying. Dramatization is a way of paying attention to educational practices, and to take care of our abstractions of these practices. It aims at an "intensification of experience" (Debaise, 2017, p. 77) and the tales being told are tools that set things in motion, that can be used to think with, to construct. A post-critical way of developing theory constructs its concepts by paying attention to the particular actuality of an educational practice while telling its story, while dramatizing an educational event.

These post-critical stories are never 'moral stories' in the sense that they tell us what is wrong and what is right, or that these stories set an example to be followed. Instead, in the words of Stengers (2015), these post-critical stories could be called "technical stories" (p. 132), which means that they recount how the achievement of a certain educational event had become possible, which constraints had to be reckoned with, and how different entities (e.g., social, material, spiritual), each in their own way, belonged to a specific educational practice and contributed to the realization of this event. Rather than demanding to be followed, these post-critical stories make us think about an actual practice and inspire the becoming of different possible practices.

Dramatization aims at generating "situated knowledge” (Haraway, 1991, p. 198). This is knowledge that only acquires its relevance in relation to a specific educational practice and problem that had situated the adventure of learning that has brought this knowledge into being. In that sense, the nature of this knowledge is different from conclusive expertise, and induces moments of hesitation or slowing down. The 'perhaps' that is uttered when slowing down indicates the production of an interstice that suspends established conceptions of a practice (see Campus in Camps as political activism), and opens up a space to reconsider what had been taken for granted. It makes us slow down around educational practices and what is educational in them by paying attention and becoming sensitive to what current modes of abstraction would otherwise neglect.

In sum, dramatization is a way of taking care of the abstractions that partake in the experience of an educational practice conceived as actual occasion. Dramatization is an "art of noticing” (Tsing, 2015, p. 17) of what otherwise would have went forgotten and makes us slow down for what otherwise would have been selfevident. For instance, paying attention to the practice of Campus in Camps - the way maps are drawn, pictures are made, reports were written - allows for noticing elements that might inform concepts related to study, rather than 
activism. In that sense, dramatization adds interest to educational practices, makes them come to matter in one way rather than another, and grants a specific sense of importance.

Proposition V: What is Ultimately at Stake in PostCritical Pedagogy is the Design of Educational Practices for the Future, Without Giving Them the Power to Define What the Future Might Look Like

While developing theory in the post-critical mode, it is vital to bear in mind that it matters which educational practices are being dramatized. In the words of Haraway: "It matters what stories make worlds, what worlds make stories" (Haraway, 2016, p. 12). This bears again on the affirmative and immanent nature of post-criticality as a future-oriented attitude in educational research. It is in affirming educational practices of the present and telling a particular story about them, drawing attention to specific features and dimensions of the pattern along which they endure, that post-critical pedagogy contributes to the design of educational practices of the future. Not only do existing practices indeed inform the tales that might perhaps be told about them, also do those tales and the concepts that are formed as part of those stories inform future practices.

In the words of Deleuze and Guattari (1991/1994), post-critical pedagogy could therefore be called a "pedagogy of the concept” (p. 12), in which every concept requires a situated story that grants it its theoretical force. This force consists in the capacity to propose new habits, new conventions, that correspond with new ways of perceiving and acting, and new ways of inhabiting the Earth. It is in taking care of our abstractions of educational practices, paying attention to what tends to be omitted, and slowing down in front of what usually goes without saying, that a concept can be forged that makes us experience this practice, including the problem it confronts, in a new way. In that regard, a pedagogy of the concept sets a double operation in motion in that it intensifies our experience of existing educational practices on the one hand, and that it creates the concepts that might perhaps inspire educational practices of the future on the other hand.

Returning to the first proposition, these concepts find their home within propositions as the stories that might perhaps be told about particular practices. These tales inhabit the middle ground between the actual occasion of an educational practice and the concepts that are mobilized to grant importance to this practice. It is in telling these tales that propositions add interest to educational practices, make them come to matter in one way rather than another. In doing so, the pedagogy of the concept that postcriticality proposes not only intensifies our experience of educational practices in the present, but also provides footholds for the design of educational practices for the future.

\section{References}

Debaise, D. (2017). Nature as event. The lure of the possible. Duke University Press.

Debaise, D., \& Stengers, I. (2017). The insistence of possibles: Towards a speculative pragmatism. (A. Brewer, Trans.). PARSE, 7, 12-19. (Original work published 2016)

Deleuze, G., \& Guattari, F. (1994). What is philosophy? (G. Burchell \& H. Tomlinson, Trans.). Verso. (Original work published 1991)

Haraway, D. J. (1991). Simians, cyborgs, and women. The reinvention of nature. Free Association Books.

Haraway, D. J. (2016). Staying with the trouble. Making kin in the Chthulucene. Duke University Press.

Hodgson, N., Vlieghe, J., \& Zamojski, P. (2018). Manifesto for a post-critical pedagogy. punctum books.

James, W. (1988). Manuscripts, essays, and notes. Harvard University Press.

James, W. (2000). Pragmatism and other writings. Penguin Classics. (Original work published 1907)

James, W. (2018). Essays in radical empiricism. Alpha Editions. (Original work published 1912)

Savransky, M. (2017). The wager of an unfinished present: Notes on speculative pragmatism. In A. Wilkie, M. Savransky, \& M. Rosengarten (Eds.), Speculative research: The lure of possible futures (pp. 25-38). Routledge.

Schildermans, H. (2021). Experiments in decolonizing the university. Towards an ecology of study. [Manuscript in preparation]. Bloomsbury.

Sehgal, M. (2014). Diffractive propositions: Reading Alfred North Whitehead with Donna Haraway and Karen Barad. Parallax, 20(3), 188-201.

Stengers, I. (2014). Thinking with Whitehead. A free and wild creation of concepts. (M. Chase, Trans.). Harvard University Press. (Original work published 2002) 
Stengers, I. (2015). In catastrophic times. Resisting the coming barbarism. (A. Goffey, Trans.). Open Humanities Press. (Original work published 2009)

Tsing, A. L. (2015). The mushroom at the end of the world. On the possibility of life in capitalist ruins. Princeton University Press.

Whitehead, A. N. (1968). Modes of thought. The Free Press. (Original work published 1938)

Whitehead, A. N. (1978). Process and reality. An essay in cosmology. (Corrected edition by D. Griffin \& D. Sherburne). The Free Press. (Original work published 1929)

\section{Recommended Citation}

Schildermans, H. (2020). Adding interest to educational practices. Propositions for a post-critical pedagogy. On Education. Journal for Research and Debate, 3(9). https://doi.org/10.17899/on_ed.2020.9.12

About the Author

Hans Schildermans is a postdoctoral researcher at the Center for Foundations of Education at the University of Vienna. He is the author of Experiments in Decolonizing the University. Towards an Ecology of Study (Bloomsbury, 2021). His research areas include the history and theory of higher education, and contemporary pragmatist philosophies of education. He is currently working on a project about the university and the quest for useful knowledge.

\footnotetext{
${ }^{1}$ I would like to thank Naomi, Joris, and Piotr for the many stimulating discussions on post-critical pedagogy which helped me to sharpen my own position. I would also like to thank the organizers and participants of the colloquium on post-criticality at the University of Tübingen in February 2020, and the editors of the journal for inviting me to write down my thoughts on the topic.
} 